九州大学学術情報リポジトリ

Kyushu University Institutional Repository

\title{
Hydrology Simulation of Ukud River in Lati Coal Mine
}

\section{Abfertiawan, M. Sonny}

Department of Mining Engineering, Bandung Institute of Technology

Gautama, Rudy Sayoga

Department of Mining Engineering, Bandung Institute of Technology

Kusuma, Syahril Badri

Department of Civil Engineering, Bandung Institute of Technology

Notosiswoyo, Sudarto

Department of Mining Engineering, Bandung Institute of Technology

https://doi.org/10.5109/1657737

出版情報: Evergreen. 3 (1)，pp.21-31，2016-03. Green Asia Education Center バージョン：

権利関係 : 


\title{
Hydrology Simulation of Ukud River in Lati Coal Mine
}

\author{
M. Sonny Abfertiawan ${ }^{1}$, Rudy Sayoga Gautama ${ }^{1}$, Syahril Badri Kusuma², \\ Sudarto Notosiswoyo ${ }^{1}$
}

\author{
${ }^{1}$ Department of Mining Engineering, Bandung Institute of Technology, Indonesia \\ ${ }^{2}$ Department of Civil Engineering, Bandung Institute of Technology, Indonesia \\ *Author to whom correspondence should be addressed, \\ E-mail: sonny_abfertiawan@yahoo.com
}

(Received January 20, 2016; accepted February 24, 2016).

\begin{abstract}
Development of mine pit and overburden disposal has caused dynamic changes in the catchment area of Ukud River, one of the rivers that flow through Lati Mining Operation. The maximum discharge of the river reached $13 \mathrm{~m}^{3} /$ second and the catchment area occupied a total area of 1901.7 hectares. Since the mining operations started, the river discharge fluctuations have changed considerably. In addition, the catchment area that was dominated by overburden disposal area contained sulphide minerals that potentially degrade the water quality of Ukud River due to the formation of acid mine drainage. Hydrological studies are essential to investigate potential environmental impacts of the mining activities. This study was conducted to determine the characteristics of the hydrologic systems in the mining area using semi-distributed models that can be used to simulate the river flow within catchment area.
\end{abstract}

Keywords: topmodel; hydrology; runoff; coal mine; acid mine drainage.

\section{Introduction}

Indonesia is one of the countries that use coal as a primary energy source. With coal reserves reached 21 billion tons, Indonesia has $62 \%$ of primary energy that generated from coal in 2014. Therefore, the development of the mining industry continues to be developed in two main basins which have the largest reserves such as Sumatra and Borneo. Coal production increased to 350 million tons in 2015.

Open pit coal mining is a surface mining technique where coal is extracted by digging, hauling, and stockpiling overburden to disposal area. To extract the coal, mining operations are carried out through the excavation and transport of overburden material in relatively large amounts. This activity could potentially have a negative impact on the environment that changes in topography and land cover. There are two main issues related to this potential impact. Fluctuation of discharge occurred due to changes in catchment area and the physical characteristics of the land such as the vegetation, slope, and the characteristics of the rocks in the disposal area. While water flow conditions both surface and ground water potential decreased quality influenced by erosion and the presence of minerals in the overburden. Overburden potentially contain sulfide minerals that can oxidize when exposed and in contact with oxygen in the air. Oxidation of sulfide minerals potential to generate

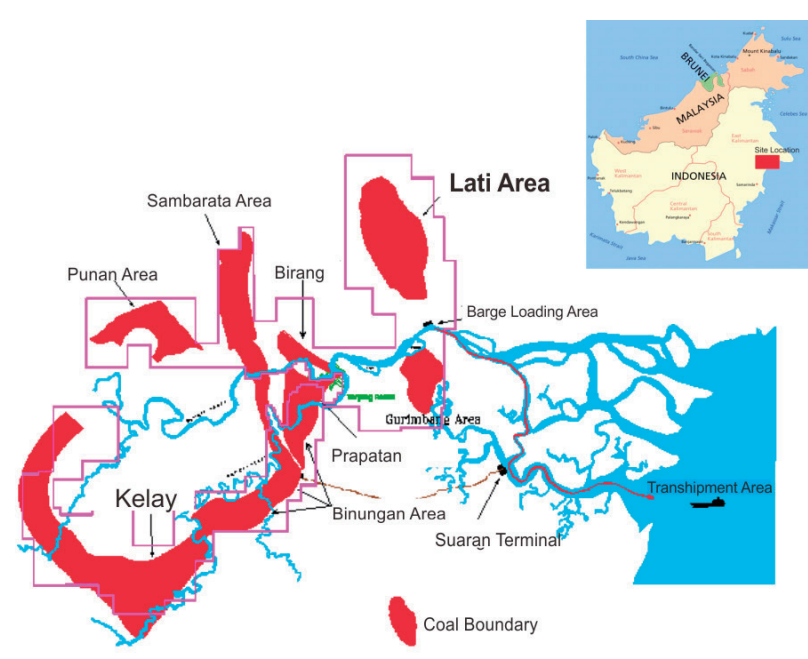

Fig. 1. Lati Mine Operation.

acid mine drainage (AMD), which has a low $\mathrm{pH}$ and transport the products of oxidation such as $\mathrm{SO}_{4}^{2-}, \mathrm{Fe}^{2+}$, $\mathrm{Al}^{3+}$ and $\mathrm{Mn}^{2+}$ (Foos, 1996). The potential impact of these changes will continuously occur follow the plan of mining and mine closure. Therefore, environmental management based on catchment area approach will be affected by mining activity should be integrated with the mine plan.

Ukud River is located in the southern part of Lati Coal 
Mine, Berau, East Kalimantan with a length of approximately $8 \mathrm{~km}$ (Figure 1). This river is one of the tributaries Lati that flow into Segah River, the main river in the city of Berau. Based on data from Environmental Impact Assessment (EIA) documents in 1989, Ukud River have good quality with $\mathrm{pH}$ value range from 5.6-6.5. Concentration of sulfate was recorded in range between 20 to $25 \mathrm{mg} / \mathrm{L}$. Other parameters also showed the value that meets the government environmental quality standards. However, since the mining operations in the 1990s, both hydrological characteristics Ukud River and quality began to change. Ukud catchment area experiencing changes due to excavation and dumping of overburden materials that have an impact on the hydrological conditions and its water quality. The change can be seen from the discharge and quality monitoring. See Figure 2. In 2013, the maximum discharge Ukud River reaches $13 \mathrm{~m} / \mathrm{s}$ during the rainy season. But in the dry season, Ukud River tends not flowing. Furthermore, Ukud River also has been indicated to be impacted by past mining activity and overburden disposal. It is characterized by low $\mathrm{pH}$ caused by AMD generated mainly in overburden dump. The sulfate concentration also increases up to $400 \mathrm{mg} / \mathrm{L}$. Fluctuation of discharge and water quality of Ukud River in 2013 can be seen in Figure 2. Acid mine drainage can potentially have an impact on ecological systems and water due to toxicity and low $\mathrm{pH}$ after mining operations are closured (Cherry et al., 2001). In addition, deposition of suspended material from acid mine water is also harmful to organisms in aquatic systems (Achterberg et al., 2003).

Since quality and quantity are closely related, these aspects must be considered together in the study to evaluate their characteristic and possible effect in environmental (Agnew and Corbett, 1969). The ability to make hydrological predictions also has become an essential part of sustainable management of water resources, water quality and water-related natural hazards (H. Lee et al, 2007). In an open pit coal mine, hydrology has become an interesting and important point to be studied within the mine environment management, particularly in relation to the AMD. The generation of AMD involves a complex process that can be influenced by many factors such as mineralogy, hydrology, geology, and climatic conditions (White et al. 1999). Therefore, some study needs to be conducted to evaluate this process.

This paper focus on hydrological model in catchment area that impacted by AMD. The model was conducted by using the semi-distributed hydrological model TOPMODEL developed by Beven (1975). Previous studies have shown that this method can be used to simulate and predict watershed runoff and its capability to application in a wide range of watershed. Sun and Deng (2003) used TOPMODEL for rainfall-runoff in the Soumou River Catchment, a tributary of the Yangtze River. Nourani, et al. (2011) used this model for rainfall-runoff in Ammameh watershed with different terrain algorithms. TOPMODEL also has been used successfully by Zanon (2011) for rainfall-runoff model in tropical rainforest watershed. Beneche (2013) used this method to simulate the discharge of Grise River in order to estimate the flood condition.

In this present study, TOPMODEL was used to simulate runoff in catchment area that impacted by mining activities. This is become interesting since the catchment area change dynamically and periodically following the sequence of mine plan. This is an initial study to integrate the hydrological model with a chemical model that aimed to evaluate the generation of AMD in the Ukud catchment area.

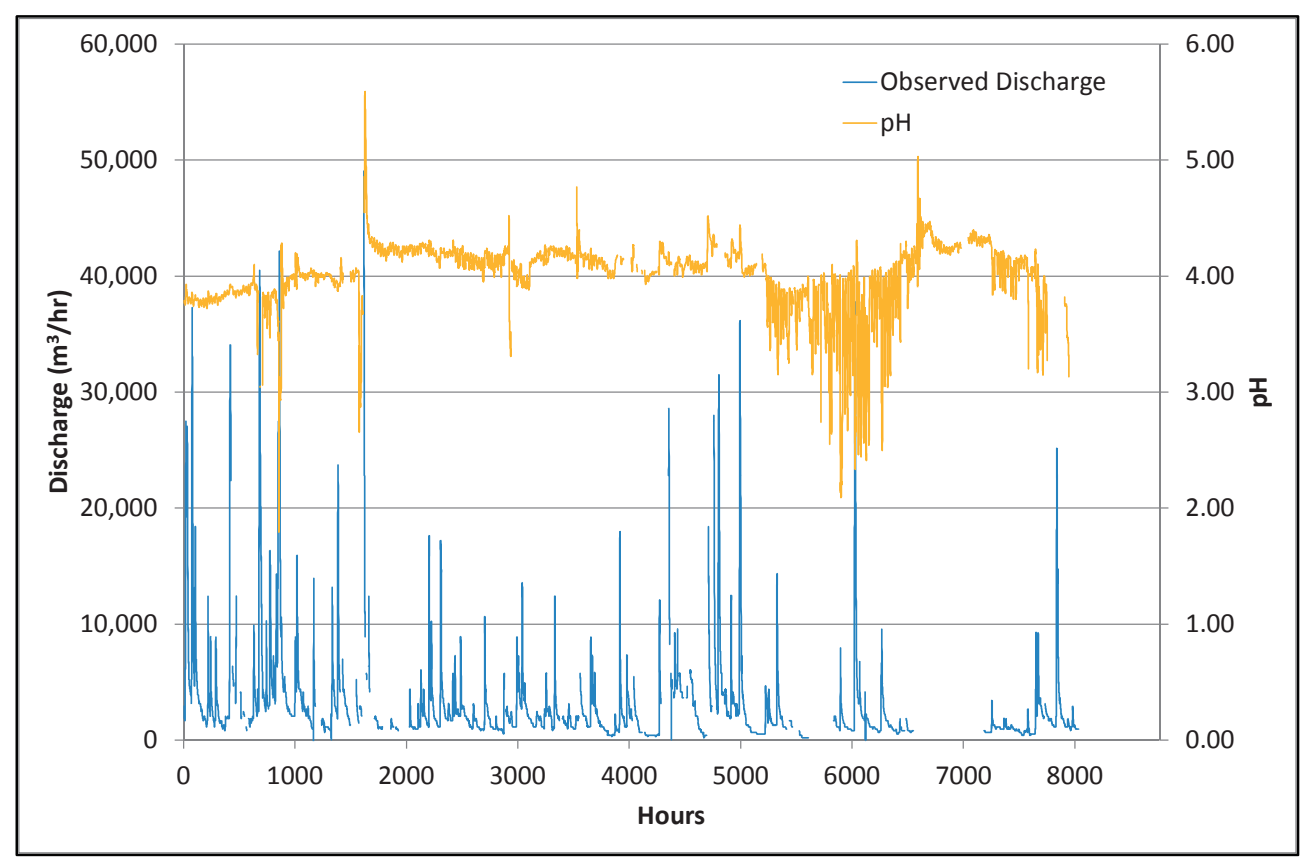

Fig. 2. Discharge and Water Quality of Ukud River in 2013. 


\section{Site Description}

Ukud catchment area changes dynamically and periodically in line with mine activities. Before 1990, Ukud River has a catchment with an area of $1681.63 \mathrm{Ha}$. Currently, after 1990s, the catchment has an area of 1901.7 Ha with different boundary and geometry of catchment area. The watershed elevation ranges from -14 $\mathrm{m}$ to $130 \mathrm{~m}$ from sea level. Around $48.6 \%$ of this area has been used for overburden disposal area, whereas the rest portion of the area $(51.4 \%)$ remains natural and undisturbed. Only $48 \%$ of the disturbed area has been re-vegetated. These changes have profound impacts on stream flow conditions.

Ukud River is classified as episodic stream since there is no flow during dry season. Ukud River has shown changes in discharge fluctuations as well as water quality due to backfilling of overburden material within the catchment area, which results in topographic changes, both in terms of elevation and width. In 2013, some instruments were installed to measure Ukud River's discharge continuously. This monitoring presents an average flow of $0.65 \mathrm{~m}^{3} / \mathrm{s}$. Despite the absence of discharge data before the mining activities started, these flow rates were quite high that could be seen from the flooding conditions around the stream.

Furthermore, since the majority of overburden materials on the LMO were identified as Potentially Acid Forming (PAF) and there was no segregation between PAF materials and Non-Acid Forming (NAF) materials, the water quality of Ukud River decreased with range from 3.96 to 4.5 (Abfertiawan, 2013), which was acidic and below the goverment environmental quality standard. It seems that this condition will continue to occur in the future, as the mining and reclamation activities progress.

\section{Methods}

\subsection{TOPMODEL Concept}

Hydrological model has evolved over three decades with different concepts and approaches. The model was developed from a simple method to very complex involving space and time. The development model is also followed by the development of observation methods involving measurement instruments hydrologic components so it is believed that the development of the method in hydrological modeling will be very dynamic.

There are two types of models commonly used i.e. deterministic and stochastic models. Hydrological deterministic model is often called physically based, which describes the actual hydrological system to simulate the actual hydrological cycle, for example, the simulation of rainfall into a hydrograph. There are two types of this model that are lumped model and distributed models. The stochastic model is a method of applying statistics to assess the hydrological conditions. Stochastic hydrology is only useful in the design or in making operational decisions. It is difficult to understand the characteristic of catchment area as well as the hydrologic component.

Lumped model is a model where the catchment area is assumed to be a unit. This method is relatively simple because it does not incorporate all of the components of hydrology in detail. In contrast, the distributed model is a model developed in a way to divide the catchment into several units, each of which has different characteristics. This is the most complicated model. Generally, this model involving differential equations is quite complicated.

One of the hydrological models that has evolved and well known is TOPMODEL. TOPMODEL is a semi-distributed model developed by Beven and Kirkby

\begin{tabular}{|c|c|}
\hline $\begin{array}{l}\text { Vegetation } \\
\text { Zone }\end{array}$ & $\mathrm{Et}_{0}=\mathrm{ET}\left(1-\left(\mathrm{D}_{\mathrm{rz}} / \mathrm{D}_{\mathrm{rz}_{-} \max }\right)\right)$ \\
\hline \multirow[t]{2}{*}{$\begin{array}{l}\text { Root } \\
\text { Zone }\end{array}$} & $D_{r_{-} \max }=\left(\theta_{\mathrm{fc}}-\theta_{\mathrm{wp}}\right)\left(z_{\mathrm{rz}}\right)=\Delta \theta_{2}\left(z_{\mathrm{r}}\right.$ \\
\hline & $D_{r z}=D_{r z-1-1-1}$ \\
\hline
\end{tabular}

Unsaturated

Zone

\section{Saturation \\ Zone}

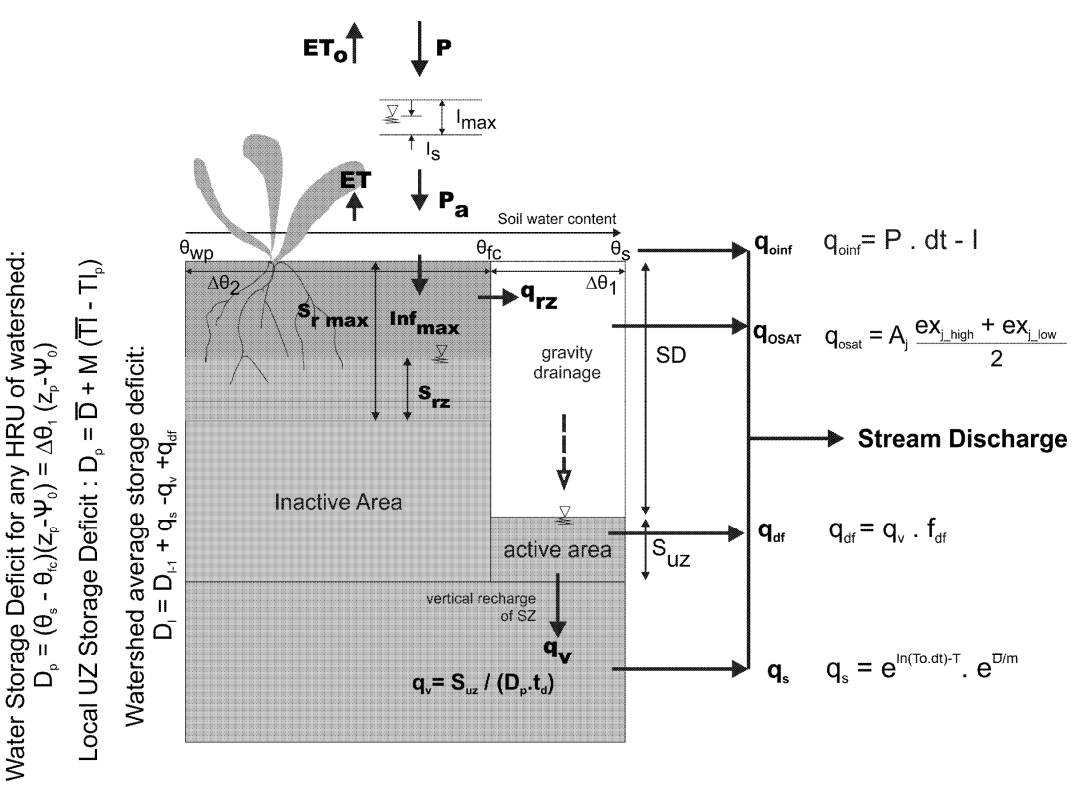

Fig. 3. Concept of TOPMODEL. 
(1979). It is one of several hydrological simulation methods that propose a relatively simple approach compared to the more complex hydrological models used to simulate hydrologic components, particularly runoff. Moreover, TOPMODEL gives the compromise between the complexity of the fully-distributed model and the simplicity of the lumped models (Nourani, et al., 2011).

TOPMODEL was developed by applying grid cell approach to the topography of a catchment area. Every grid cell of the topographic data was defined with specific value related to component of hydrologic, namely Hydrological Response Unit (HRU). In TOPMODEL, the HRU was defined by Topographic Index (TI) that could be obtained by analyzing the topographic data. According to Beven et al. (1995), TOPMODEL is developed base on three assumptions: (1) dynamics of a saturated zone can be described as a succession of steady state conditions; (2) the local saturated zone hydraulic gradient can be represented as the surface slope of topography $(\tan \beta)$; and (2) distribution of the soil transmissivity with depth is an exponential function of storage deficit.

In the development of hydrologic models using TOPMODEL, There are two storage concern, namely the root zone storage and storage unsaturated zone. These components are the most important variables in TOPMODEL. TOPMODEL concept can be illustrated as in Figure 3. When rain falls in a catchment area, then TOPMODEL will first evaluate whether the rainwater can be directly infiltrated. If it doesn't, the water will flow directly on the surface, while if it does, then the water will flow into the root zone. Furthermore, the model will test whether the water content in the root zone has been above the maximum limit or not. If it does not, the water will flow into the unsaturated zone and some will evaporate (evapotranspiration). If the water content still below the maximum limit of the rooting zone, there will be no water flowing into the unsaturated zone. Gravitationally, the water flows to the saturated zone storage. The model will reevaluate whether the storage of unsaturated zone already at maximum capacity. If it does, then the saturation excess overland flow will occur. It should be noted that water storage in the unsaturated zone will not flow fully due to saturation excess overland flow. Water storage in the unsaturated zone will flow out through two-way flows towards the saturated zone and direct interflow.

\subsection{Observation Data}

Discharge measurement was conducted at downstream using a rectangular weir with $5.3 \mathrm{~m}$ of length. Water level over the weir crest was measured on an hourly basis using camera traps. The obtained results were used to determine the discharge by using the Francis equation that described on Equation 1 for calculating the discharge with $h$ is the water level over the weir and $b$ is the wide of rectangular weir.

$$
Q=3.33(b-0.2 h) h^{3 / 2}
$$

The measurement was conducted during January to December, 2013. The results show the fluctuation of discharge at downstream of Ukud River with $13.63 \mathrm{~m}^{3} / \mathrm{s}$ of maximum discharge. The summary of discharge fluctuations are presented in Table 1 and Figure 4. These data were used for model calibration and validation.

Rainfall data were measured on an hourly basis using a Decagon ECRN-100 high resolution rain gauge (0.2 $\mathrm{mm}$ ) and a decagon Em50 digital/analog data logger that were installed in 2012. The rain gauge was installed in one of Ukud sub-catchments, which was assumed to represent the whole Ukud catchment. The maximum hourly precipitation is $48.51 \mathrm{~mm}$. Based on daily totals in

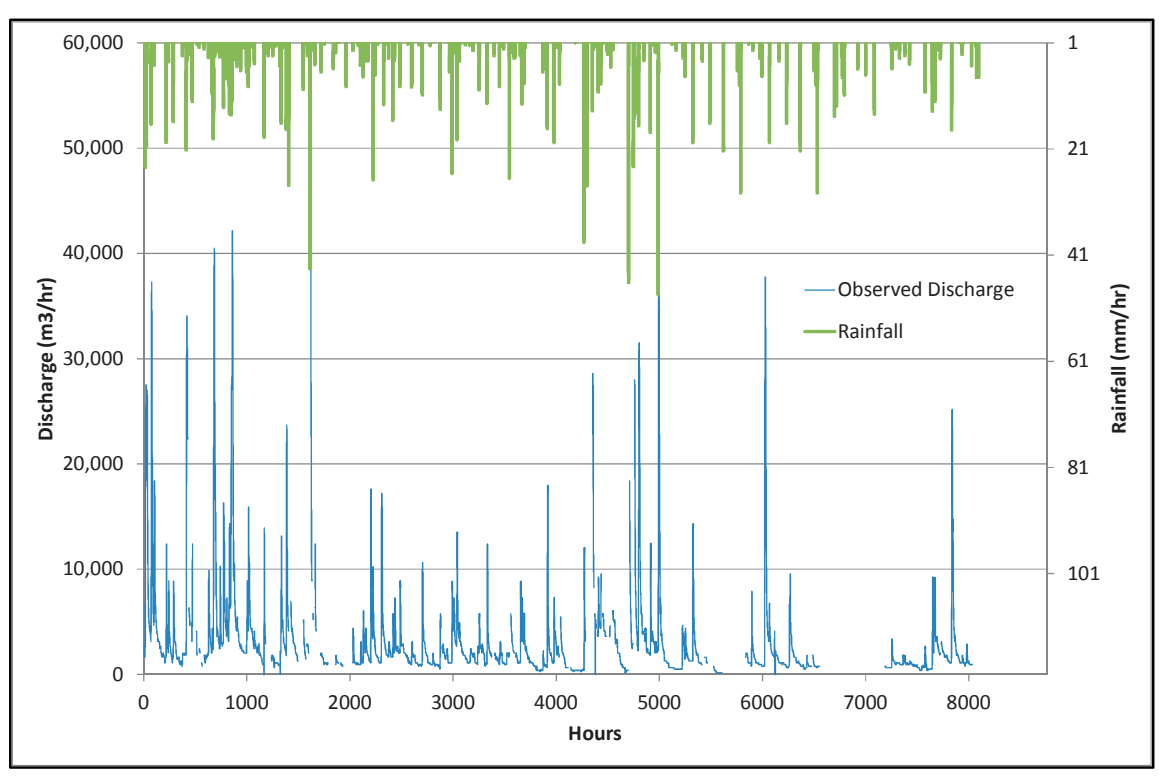

Fig.4. Observed discharge and rainfall in 2013. 
2013, the maximum monthly precipitation can reach up to $389.81 \mathrm{~mm}$. January, February, and December are the month with high rainfall intensity which occurs during the rainy season. The rainfall measurement data are shown in Figure 2 and Table 1.

Evapotranspiration is the important component in hydrological simulation. In this study, there was no specific instrument directly applicable for measuring evapotranspiration, particularly when hourly-based data were required. There are, however, methods that have been used to obtain potential evapotranspiration (PET) values. Compared with other complex methods, Hamon method that developed by Hamon (1961) is fairly simple since it only requires daily mean temperature and day length to estimate the PET. PET was calculated using Equation 2-4.

Table 1. Ukud Catchment Area Characteristics.

\begin{tabular}{|c|c|c|}
\hline & & 2013 \\
\hline \multirow{2}{*}{$\begin{array}{l}\text { Discharge } \\
\left(\mathrm{m}^{3} / \mathrm{sec}\right)\end{array}$} & Max. & 13.63 \\
\hline & Average & 0.65 \\
\hline \multirow{3}{*}{$\begin{array}{l}\text { Rainfall } \\
\text { Intensity } \\
\text { (mm/hour) }\end{array}$} & Min & 0 \\
\hline & Max & 48.51 \\
\hline & Average & 0.30 \\
\hline \multirow{3}{*}{$\begin{array}{c}\text { PET } \\
\text { (mm/day) }\end{array}$} & Min & 3.90 \\
\hline & Max & 2.95 \\
\hline & Average & 3.35 \\
\hline \multirow{3}{*}{$\begin{array}{l}\text { Temperature } \\
\left({ }^{\circ} \mathrm{C}\right)\end{array}$} & Min & 36 \\
\hline & Max & 20 \\
\hline & Average & 27.03 \\
\hline
\end{tabular}

$P E T=C\left(\frac{D L}{12}\right)^{2} P_{t}$

$P_{t}=\frac{e^{*}}{\left(T_{e m p_{a}}+273.15\right) R_{v}}$

$e^{*}=0.611 \times e^{\left[\frac{17.3 \times T_{\text {empa }}}{T_{e m p a}+273,3}\right]}$

DL refers to the Day Length (hours/day), which is obtained by using a spreadsheet from the National Oceanic and Atmospheric Administration (NOAA) USA (Chris Cornwall, 2016). Variation of DL showed no significant difference since the study area located near from the equator. Pt refers to the density of saturated water vapor in the air or humidity on daily average temperature $\left(\mathrm{g} / \mathrm{m}^{3}\right)$. The constant $\mathrm{C}$ refers to the value of study area condition in units of inches/day. $\mathrm{T}_{\text {empa }}$ refers to the average daily temperature in the air in Celsius. $\mathrm{Rv}$ refers to the gas constant $0.463 \mathrm{kPa} /\left(\mathrm{K}^{*} \mathrm{~kg}^{*} \mathrm{~m}^{-3}\right)$.

\subsection{Simulation Methods}

\subsubsection{Digital Elevation Model (DEM)}

Evaluation and analysis of DEM were carried out using ArcMap application based on existing topographic data. These data also had been used to identify the changes of topography caused by development of mining sequence and revegetation progress. The topographic data were interpolated into $30 \mathrm{~m}$ of resolution. This is an important step in TOPMODEL. It will greatly determine TI values and quality of the model results. The TI describes the wetness index that was originally developed by Beven and Kirkby (1979). If the DEM is too coarse, some elements of hydrology will not be present on the TI map. Therefore, the determination of the value of DEM resolution is very important to get good results.

Ukud catchment area has range in elevation between -14 to $130 \mathrm{~m}$ from sea level. The lowest being the floor of the abandoned-mine pit, which was filled with water as shown in Figure 5. Furthermore, the DEM data are used to analyze the contributing area $(\alpha)$ and slope $(\beta)$. Both of these data are the basic data to obtain the TI distribution. The analysis was performed using tools in ArcMap.

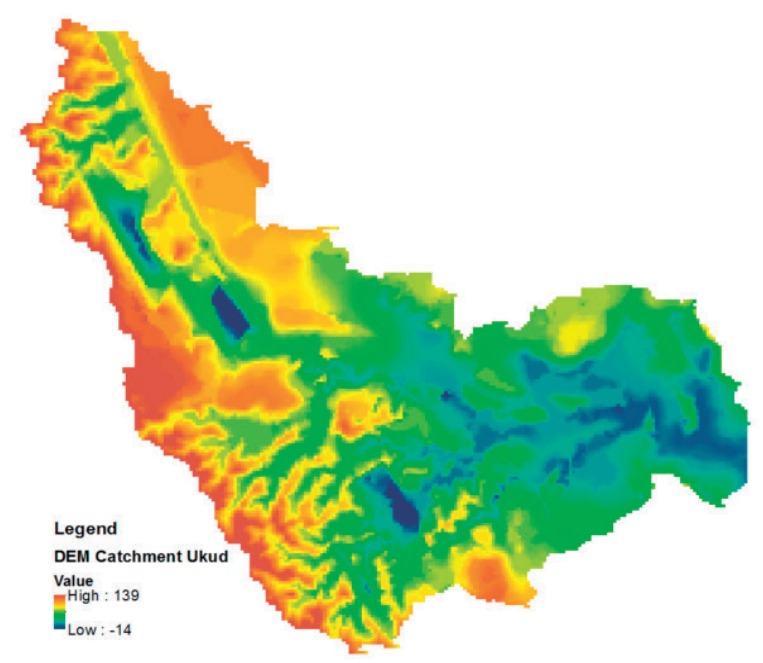

Fig. 5. Topograpy of Ukud Catcment Area.

\subsubsection{Topographic Index (TI)}

The TI distribution was obtained using the following equation:

$\lambda=\ln \left(\frac{\alpha}{\tan \beta}\right)$

Where $\alpha$ (upslope contributing area) is the local upslope area draining through a grid cell of the catchment per unit contour length, which was obtained by using the flow accumulation tool in ArcMap and $\beta$ is the local slope in degrees, which was analyzed using the slope tool in the Spatial Analyst extension of ArcMap.

The slope of the catchment area affects how quickly water will runoff during a rain event. From DEM 
analysis, Ukud catchment area has variety of slope with range from 0 to 33.6 degree. Area with zero degree means flat area that was categorized as disposal area and riverbank. In topographic index, the flat area has a high value of TI. See Figure 6-8.

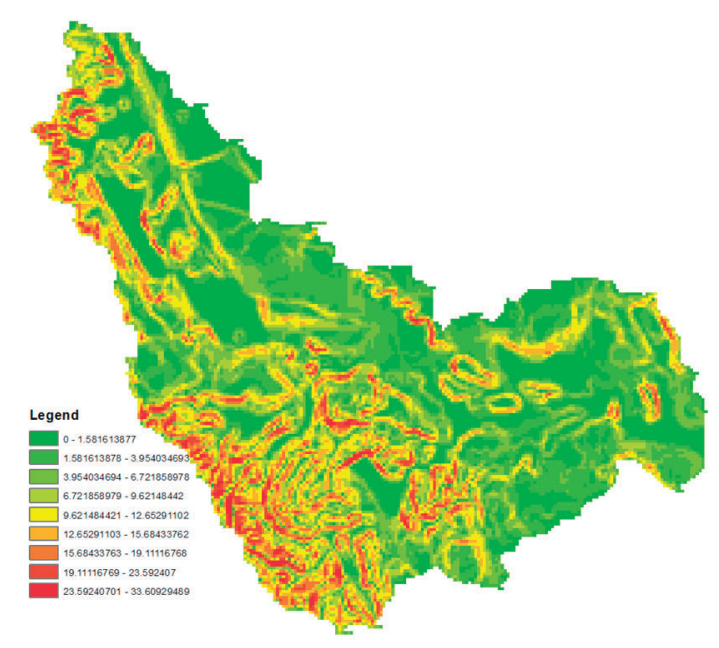

Fig. 6. Slope Distribution of Ukud's Catcment Area.

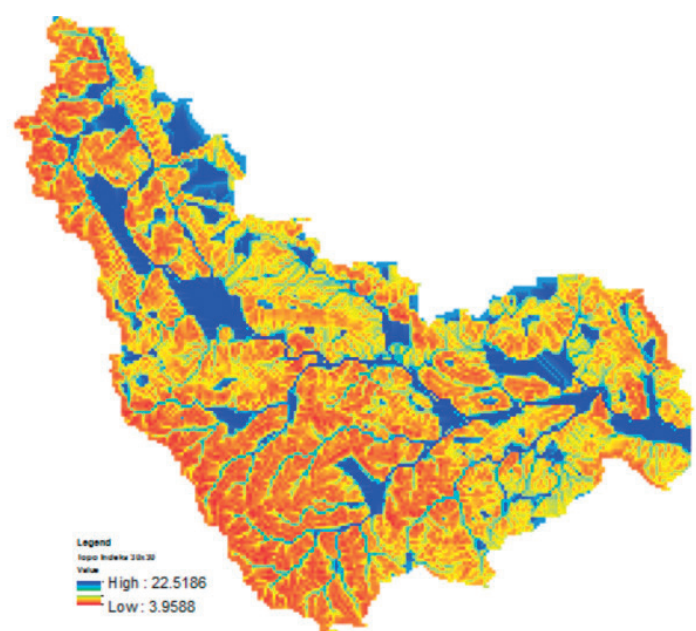

Fig. 7. TI Distribution of Ukud's Catcment Area.

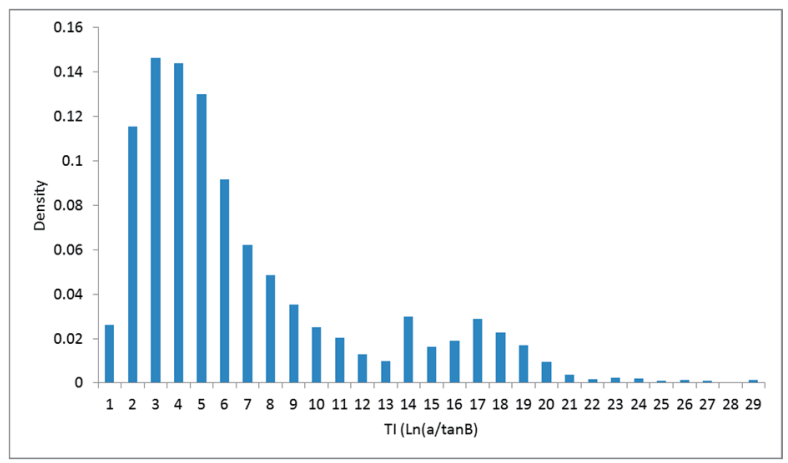

Fig. 8. TI Distribution of Ukud's Catcment Area.

\subsubsection{Time Delay Distribution}

The time delay distribution refers to the distance between a reference point at downstream (in this case: location of the weir) and each grid cell within the catchment area. The analysis was conducted using the flow length tool in ArcMap. The results are presented in the following table.

Table 2. Time Delay Distribution.

\begin{tabular}{cc}
\hline Distance $(\mathbf{m})$ & Accumulation Area \\
\hline 0 & 0 \\
1087.87 & 0.078 \\
2175.75 & 0.155 \\
3263.62 & 0.293 \\
4351.5 & 0.440 \\
5439.37 & 0.614 \\
6527.25 & 0.782 \\
7615.12 & 0.883 \\
8703.00 & 0.962 \\
9790.87 & 1 \\
\hline
\end{tabular}

\subsubsection{Model Input}

In addition to meteorological data and TI, the following input parameters are required to simulate the hydrologic system of the catchment area using TOPMODEL:

a. Saturated hydraulic conductivity at the surface $\left(\mathrm{K}_{0}\right.$, $\mathrm{cm} / \mathrm{hr}) \cdot \mathrm{K}_{0}$ is generally a value that describes the ability of water to flow through porous media under saturated conditions. This value has an important role in determining the discharge of runoff, infiltration, and percolation in the hydrological system. Hydraulic conductivity is strongly influenced by the physical medium characteristic.

b. Transmissivity of the fully saturated soil $\left(\mathrm{T}_{0}, \mathrm{~m}^{2} / \mathrm{hr}\right)$. $\mathrm{T}_{0}$ is defined by the product of the saturated thickness and the hydraulic conductivity of the soil (Fetter, 2001).

c. The M Parameter (scaling parameter for discharge reseccion). M parameter values can be obtained using approach of discharge data (Beven, 2001).

d. Initial root zone storage deficit ( $\mathrm{D}_{\mathrm{rz}}$ init, meter).

e. The maximum moisture deficit in the root-zone ( $\mathrm{D}_{\text {rz } \max }$, meter).

f. Vertical time delay for recharge of the Saturated Zone (td, hr/m). Parameter of td is a retention time of water required in the unsaturated zone water storage deficit Dp (Beven, 2001) before it flows to saturated zone. These parameters do not have a considerable influence on the simulation results of TOPMODEL.

g. Channel routing velocity $(\mathrm{Vr}, \mathrm{m} / \mathrm{hr})$. $\mathrm{Vr}$ is the stream velocity derived from observation discharge value 
divided by the cross section of the body of the river. h. Initial subsurface Flow ( $\mathrm{q}_{\text {s_init, }} \mathrm{m} / \mathrm{hr}$ ).

The simulations were run using the $\mathrm{R}$ package TOPMODEL which was originally developed by Wouter Buytaert (2011). There were two stages conducted in this study. At the first stage, the hydrological model was evaluated in terms of the above parameters. The analysis was performed with a range of values for each parameter (as shown in Table 3). Furthermore, those parameters were programmed to run 1200 iterations in order to obtain 1200 sets of parameters.

Table 3. Input Parameter.

\begin{tabular}{cccc}
\hline Symbol & unit & Min & Max \\
\hline $\mathrm{dt}$ & hour & & 1 \\
$\mathrm{~T}_{0}$ & $\ln \left(\mathrm{m}^{2} / \mathrm{hr}\right)$ & 0.1 & 20 \\
$\mathrm{~K}_{0}$ & $\mathrm{~m} / \mathrm{hr}$ & 0 & 3 \\
$\mathrm{M}$ & $\mathrm{meter}$ & 0 & 0.15 \\
$\mathrm{D}_{\mathrm{rz} \text { init }}$ & $\mathrm{meter}$ & 0 & 1 \\
$\mathrm{D}_{\mathrm{rz} \text { max }}$ & $\mathrm{meter}$ & 0 & 1 \\
$\mathrm{Td}$ & $\mathrm{hr} / \mathrm{m}$ & 0 & 1000 \\
$\mathrm{Vr}$ & $\mathrm{m} / \mathrm{hr}$ & 100 & 1000 \\
$\mathrm{CD}$ & $\mathrm{meter}$ & 0 & 5 \\
$\mathrm{q}_{\mathrm{s} \_ \text {init }}$ & $\mathrm{m} / \mathrm{hr}$ & 0 & 0.00014 \\
\hline
\end{tabular}

Each set of parameter was calculated to obtain the simulation discharge and validated with the observed discharge data. This process is aimed to find the best performing parameter values with the smallest error values. At the second stage, simulation of discharge fluctuations was conducted using the best performing set of parameters generated from the first stage as the input parameters

\subsection{Calibration Methods}

A model calibration was conducted to obtain the best parameter set for a catchment area with the smallest error value. It will generate the simulation results with very close to the field measurement data. The model performance measure was carried out using the Monte Carlo method (Zanon, 2011), where the simulation results from each set of parameters were compared to the result of another parameter set using an equation. In this study, the equation of Nash Sutcliffe Efficiency (Nash and Sutcliffe, 1970) was used. This method is the most commonly used criterion in hydrology model. It is a normalized statistic that calculates the deviation between simulation data and observed data. The NSE was calculated as:

$N S E=1-\frac{\frac{1}{n-1} \sum_{i=1}^{n}\left(q_{s i m, i}-q_{o b s, i}\right)^{2}}{\sigma_{o b s}^{2}}$

where $\mathrm{i}$ refers to a specific time step (hr), n refers to the total number of time steps, $\mathrm{q}_{\mathrm{sim}, \mathrm{i}}(\mathrm{m} / \mathrm{hr})$ refers to the simulation discharge for time step $i$, which is based on each set of parameters, $\mathrm{q}_{\mathrm{obs}, \mathrm{i}}(\mathrm{m} / \mathrm{hr})$ refers to the observed discharge for time step $\mathrm{i}$, and $\sigma_{\mathrm{obs}}\left(\mathrm{m}^{2} / \mathrm{hr}^{2}\right)$ refers to the variance of the observed discharge data. NSE is dimensionless and can range from $-\infty$ to 1.0 (Schaefli and Gupta, 2007; Gupta, et al., 2009; Gupta and Kling, 2011).

A NSE value equal to or close to 1 means that the simulated discharge are identical or nearly identical to the observed discharge. Moreover, a value of zero means that the simulated discharge is equal to the average discharge. The NSE efficiency also can have a negative value when the residual variance is larger than the data variance. These describe that the mean value of observed data is a better predictor than the model. Therefore, negative value of NSE is generally ignored since we already have data greater than zero.

\section{Results}

\subsection{The Best Value of NSE}

The NSE results demonstrated that NSE distribution varied greatly. Only 1000 sets of parameter values have positive NSE values, while the rest (200 sets) yielded negative NSE values. Only the positive NSE values were selected for further analysis. The result of NSE analysis presented in Figure 9-13.

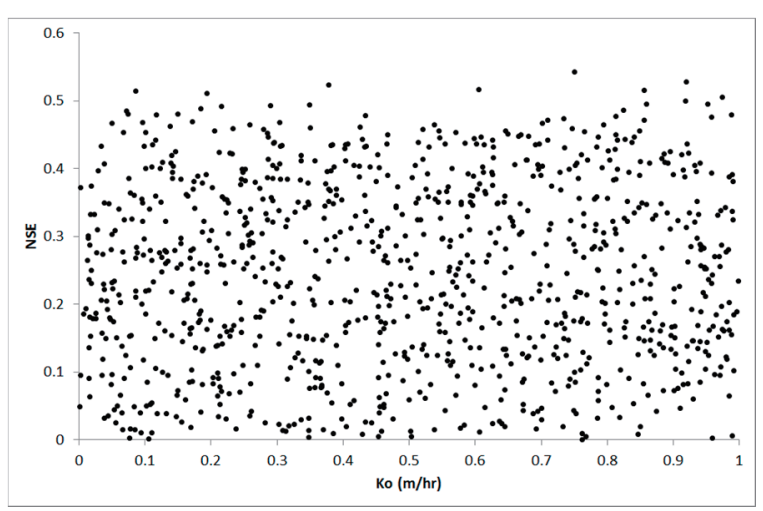

Fig. 9. Parameter $\mathrm{K}_{0}$ sensitivity with NSE $>0$.

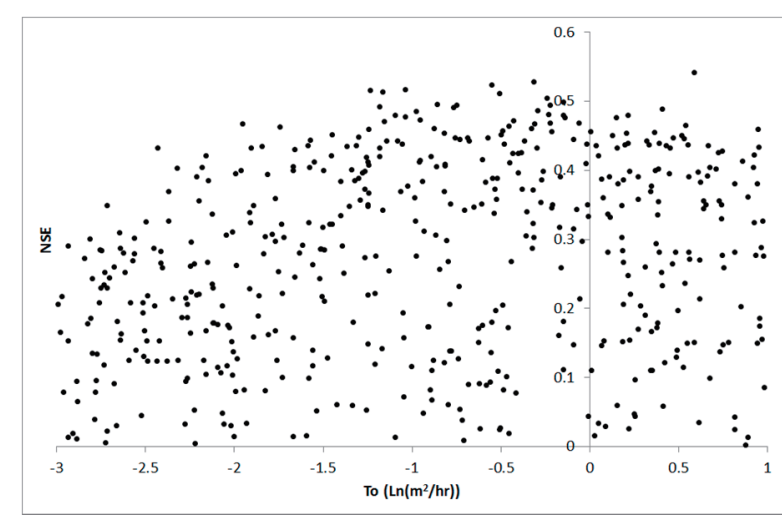

Fig. 10. Parameter $T_{0}$ sensitivity with NSE $>0$. 


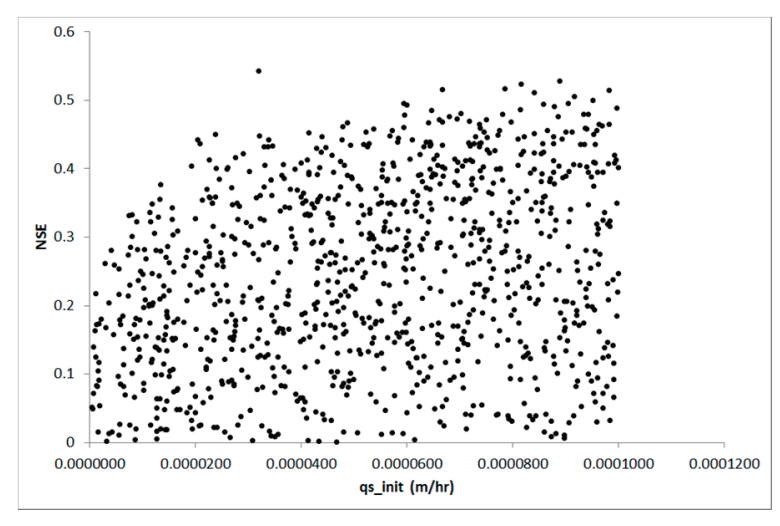

Fig. 11. Parameter $\mathrm{q}_{s} \_$init Sensitivity with $\mathrm{NSE}>0$.

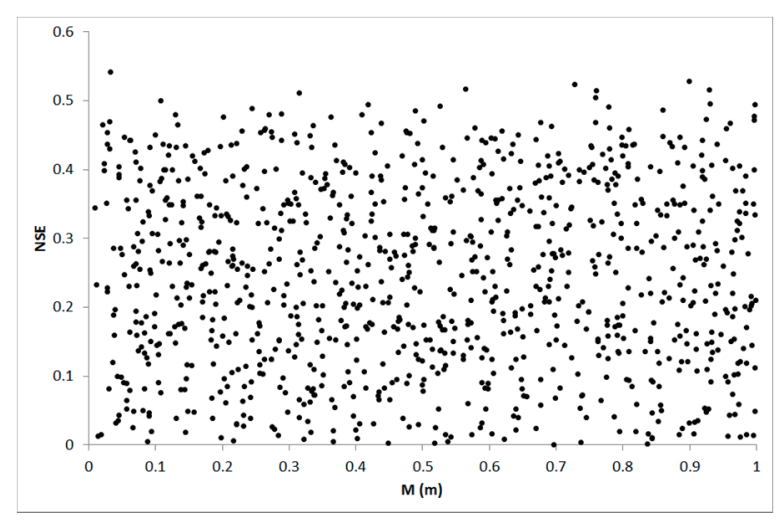

Fig. 12. Parameter M sensitivity with NSE $>0$.

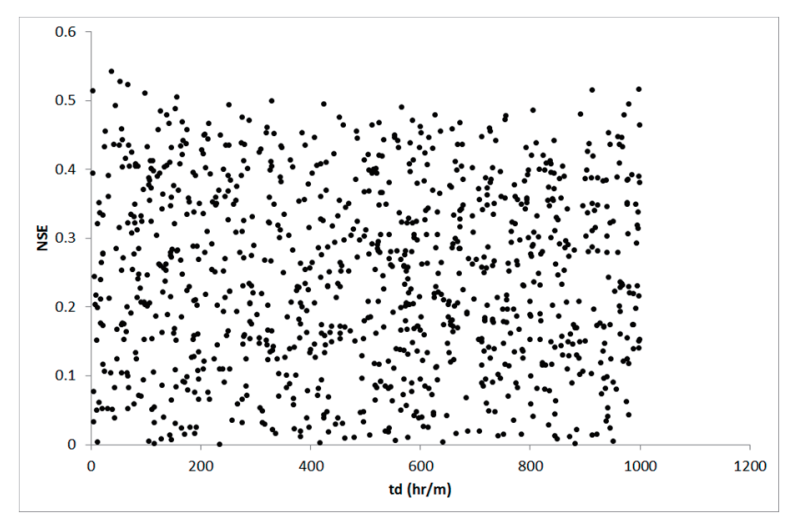

Fig. 13. Parameter td sensitivity with NSE $>0$.

From 1000 iteration, the best NSE value that can be achieved was 0.54, which was quite satisfactory according to some references. There is no specific provision related to an acceptable NSE value. But, from previous study, Freer, et al. (1996) stated that NSE values $>0.3$ were acceptable, while Campling, et al. (2002) suggested that NSE values $>0.5$ with 1,500 parameters were acceptable. Therefore, the NSE value of 0.54 as well as the corresponding set of parameter values were selected to simulate water discharge at downstream of Ukud River.

\subsection{The Best Parameters}

The best parameter values were selected to be the single input data for simulating discharges fluctuations at downstream of Ukud River. A set of parameters that yielded NSE value of 54\% were obtained and the value of each parameter is described in Table 4. After validating the modeled discharge based on the observed discharge, these parameters may be interpreted as representing the physical characteristics of Ukud catchment area.

Table 4. The best value of each parameter.

\begin{tabular}{ccccc}
\hline Symbol & unit & Min & Max & $\begin{array}{c}\text { The Best } \\
\text { Value }\end{array}$ \\
\hline $\mathrm{dt}$ & hour & & 1 & 1 \\
$\mathrm{~T}_{0}$ & $\ln \left(\mathrm{m}^{2} / \mathrm{hr}\right)$ & 0.1 & 20 & 0.59 \\
$\mathrm{~K}_{0}$ & $\mathrm{~m} / \mathrm{hr}$ & 0 & 3 & 0.75 \\
$\mathrm{M}$ & meter & 0 & 0.15 & 0.03 \\
$\mathrm{D}_{\text {rz init }}$ & meter & 0 & 1 & 0.0014 \\
$\mathrm{D}_{\mathrm{rz} \text { max }}$ & meter & 0 & 1 & 0.65 \\
$\mathrm{Td}$ & $\mathrm{hr} / \mathrm{m}$ & 0 & 1000 & 36.25 \\
$\mathrm{Vr}$ & $\mathrm{m} / \mathrm{hr}$ & 100 & 1000 & 802.88 \\
$\mathrm{CD}$ & $\mathrm{meter}$ & 0 & 5 & 0.44 \\
$\mathrm{q}_{\mathrm{s} \_ \text {init }}$ & $\mathrm{m} / \mathrm{hr}$ & 0 & 0.00014 & 0.000032 \\
\hline
\end{tabular}

\section{Discussion}

Ukud River is still facing the water quality as well as quantity problem caused by the changing of catchment area due to mining activities. Covering $48 \%$ of the total catchment area, disposal of overburden material becomes the main causes that lead to an increase in the river flow and water quality degradation. The hydrological model needs to be conducted as a part of studies that integrate hydrology aspect and water quality aspect.

The semi-distributed TOPMODEL was used to determine the characteristics of a catchment area and simulate the discharge at river downstream. This method has been considered to be relatively simple and valid for simulating the hydrologic system of a catchment area that disturbed by mining activities.

The simulation results showed the value of each input parameter after 1000 iterations has been achieved. The surface saturated hydraulic conductivity $\left(\mathrm{K}_{0}\right)$ was obtained at $0.75 \mathrm{~m} / \mathrm{hr}$ or $2 \times 10^{-2} \mathrm{~cm} / \mathrm{sec}$ with 0.54 of NSE value. The $\mathrm{K}_{0}$ value describes the ability of water to flow by gravity through a porous medium in saturated conditions. Shakoor \& Ruof (1989) stated the $\mathrm{K}_{0}$ value for the disposal area containing mudstone and sandstone in Horscley reclaimed pit, UK, was greater than $1 \times 10^{-2}$ $\mathrm{cm} / \mathrm{sec}$. Dawson \& Morgenstern (1995) stated that $\mathrm{K}_{0}$ value was $3 \times 10^{-3}$ to $1 \times 10^{-4} \mathrm{~cm} / \mathrm{sec}$ for waste rock disposal in coal and metal mines. Therefore, the $\mathrm{K}_{0}$ value of $2 \times 10^{-2} \mathrm{~cm} / \mathrm{sec}$ obtained from the simulation appeared to be valid to describe the hydrology of Ukud catchment area that was dominated by overburden disposal. 


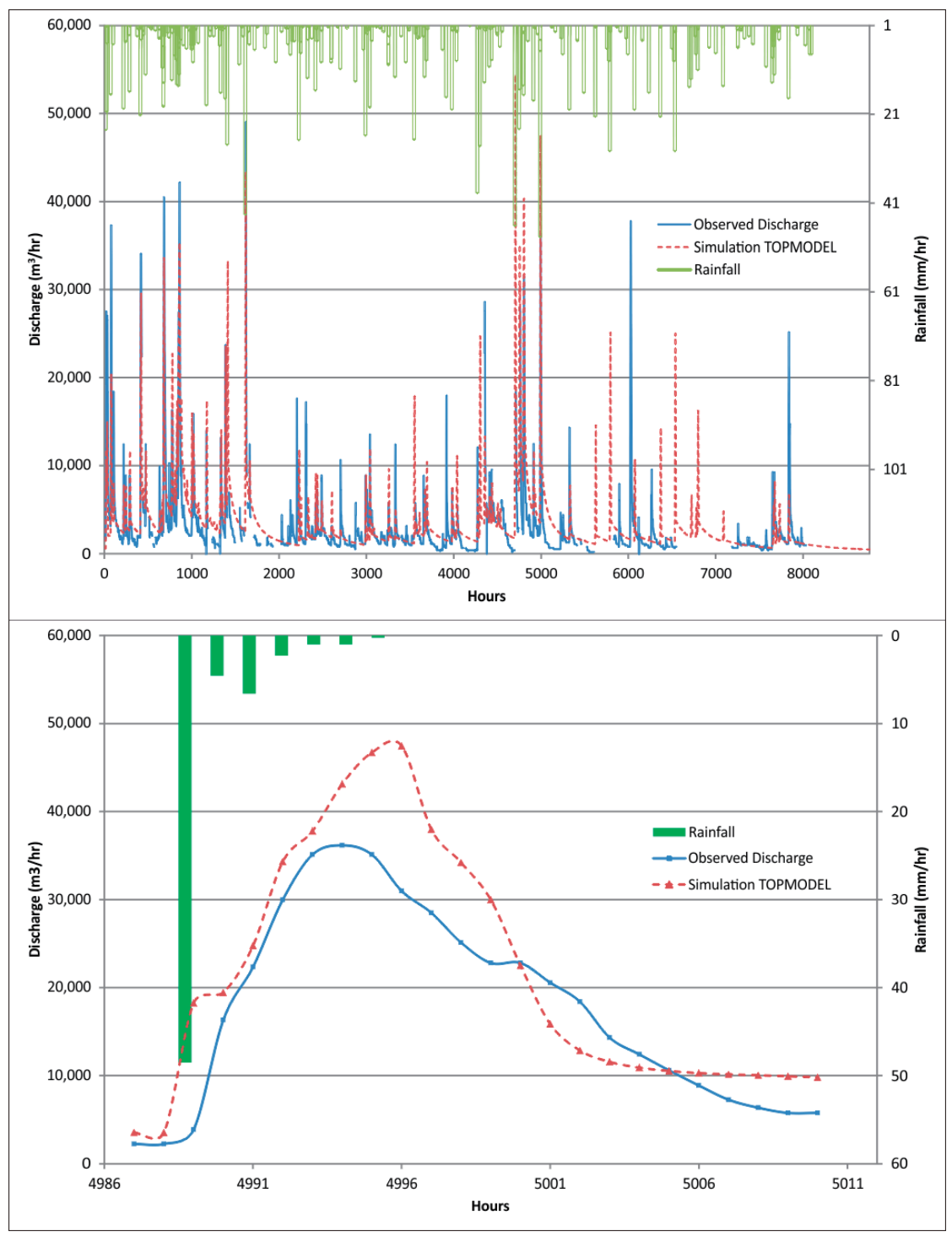

Fig.14. Simulation and Observed Discharge.

The value of $\mathrm{Vr}$ refers to the average river flow velocity. Theoretically, it can be obtained by dividing the observed discharge by the cross sectional area of the river. The simulation results showed that the flow velocity reached a value of $802.88 \mathrm{~m} / \mathrm{hr}$ or $0.22 \mathrm{~m} / \mathrm{sec}$. Ukud River's depth varied along its stream. Some segments had a depth of $5-20 \mathrm{~cm}$, while some others reached $1 \mathrm{~m}$.

Table 5. Simulation vs Observed Discharge.

\begin{tabular}{cccc}
\hline $\begin{array}{c}\text { Rainfall } \\
(\mathrm{mm} / \mathrm{hrs})\end{array}$ & $\begin{array}{c}\text { Observed } \\
\text { Discharge } \\
\left(\mathrm{m}^{3} / \text { second }\right)\end{array}$ & $\begin{array}{c}\text { Simulation } \\
\text { Discharge } \\
\left(\mathrm{m}^{3} / \mathrm{second}\right)\end{array}$ & $\begin{array}{c}\text { Deviation } \\
\left(\mathrm{m}^{3} / \text { second }\right)\end{array}$ \\
\hline 48 & 13.63 & 15.10 & 1.47 \\
19.3 & 2.94 & 3.33 & 0.38 \\
10.16 & 2.19 & 1.79 & 0.40 \\
\hline
\end{tabular}

By using the best set of parameters obtained from the first stage of simulation, the second stage of simulation was conducted to determine the discharge fluctuations in
2013, compared with the observed data. The simulation results showed that the simulated maximum discharge was $15.10 \mathrm{~m}^{3} / \mathrm{s}$ when the maximum rainfall of 48 $\mathrm{mm} /$ hour occurred. The results were quite different from the observed data, reaching the gap of $0.38-1.47 \mathrm{~m}^{3} / \mathrm{sec}$. The summary of observed and simulation discharge are shown in Figure 14 and Table 5. Hydrograph on Figure 14 shows that the discharge at downstream increased rapidly after it rains. This is associated with the landuse cover type at Ukud catchment area that dominated by disposal area. The change in landuse or physical characteristic has affected the ability of the soil to retain more water during the rain prior to direct runoff (Nobert and Jeremiah, 2012).

As studied in 2009 in the existing disposal area the PAF material is mixed with non-acid forming NAF material. Re-vegetation effort has been conducted in most of final overburden disposal area but unfortunately it could not avoid the generation of AMD as indicated in the seepages in the already reclaimed and re-vegetated disposal area having $\mathrm{pH}$ value of 3 to 4 . With the large 
flow rates, lower quality has become a serious problem in this catchment area. The dynamic change of Ukud's catchment area due to mine pit and overburden disposal development are the main challenges in AMD management in Ukud's catchment area.

\section{Summary}

Understanding hydrologic systems in mining operation area is important because the potential landscape changes due to the mining activities affect both water discharge and quality. These changes will likely continue to occur dynamically following the sequence of mine plan and during reclamation.

The TOPMODEL method was used to understand both physical characteristics of the catchment and the discharge fluctuations at downstream of Ukud River. The simulation results with the value of NSE of 54\% seem to be fairly accurate based on some related studies.

Semi-distributed hydrological model by using TOPMODEL was proven to be valid and effective to determine the characteristics of the hydrological system in Ukud catchment area that was disturbed by mining activities in Lati Mine Operation. This method can be used to model any other catchment areas with similar characteristics.

The hydrological study can be further developed to study the influence of geochemical quality and characteristics of the land cover in the overburden disposal area. Hydrological modeling, both in terms of discharge and quality, is an important consideration in mine planning. In the future, hydrology both of discharge and quality model could be integrated to mine plan in order to minimize the potential risk of AMD generation.

\section{Acknowledgement}

The authors would like to thank Asahi Foundation, Lembaga Pengelolaan Dana Pendidikan (LPDP) Indonesia, and PT Berau Coal for their support in this research.

\section{References}

1) Abfertiawan M.S. and Gautama R.S., "Development of Catchment Area Approach in Management of Acid Mine Drainage", International Mine Water Association Congress 2011, Aachen, Germany September 9 (2011).

2) Abfertiawan M.S., et al., "The Challenges in Acid Mine Drainage Management in Lati Coal Mine Operation, East Kalimantan”, International Conference on Mine Planning and Equipment Selection. Dresden, Germany (2013).

3) Achterberg, E.P., Herzl, V.M.C., Braungardt, C.B.,
Millward, G.E., "Metal behaviour in an estuary polluted by acid mine drainage: the role of particulate matter", Environmental Pollution, 121: 283-292 (2003). doi: 10.1016/S0269-7491(02)00216-6

4) Agnew, A.F., and D.M. Corbett, "Hydrology and Chemistry of Coal Mine Drainage in Indiana," 157th National Meeting of the American Chemical Society, Mineapolis, Minnesota April 13-18 (1969).

5) Beneche, Joseph Antoine, "Sensitivity And Uncertainty Analysis Of Topmodel For The Hydrological Simulation Of The Grise River Catchment" (2013).

6) Beven K.J., Freer J., "A dynamic TOPMODEL", Hydrological Processes 15, 1993-2011 (2001).

7) Beven K.J., Kirkby M.J., "A physically based, variable contributing area model of basin hydrology", Hydrological Sciences-Bulletin 24(1):43-69 (1979).

8) Beven K.J., Rainfall - Runof Modelling, The Primer. John Wiley and Sons Limited, Chichester, UK. (2001).

9) Beven K.J., Lamb R., Quinn P., Romanowicz R., Freer J., "TOPMODEL", Computer Models of Watershed Hydrology, Water Resources Publications Colorado, pp 627-688 (1995).

10) Buytaert W., "Implementation of the hydrological model Topmodel in R".

http://cran.r-project.org/web/packages/topmodel/

11) Campling P., Gobin A., Beven K., Feyen J., "Rainfall-runoff modelling of a humid tropical catchment: the TOPMODEL approach", Hydrological Processes 16(2), 231-253 (2002). DOI 10.1002/hyp.341

12) Cherry, D.S., Soucek, D.J., Schmidt, T.S., "Metal accumulation in sediment, Asian clams (Corbicula fluminea), and periphyton at selected freshwater mussel preserves in the Clinch and Powell Rivers, Virginia. Report to: The Nature Conservancy, Clinch Valley Program" Virginia/Tennessee Field Offices, Abingdon, VA. (2001).

13) Cornwall C., Horiuchi A., Lehman C., Solar calculation details (2010). http://www.srrb.noaa.gov/highlights/sunrise/sunrise. html 
14) Dawson, R. F., and N. R. Morgenstern, "Liquifaction flowslides in Rocky Mountain coal mine waste dumps", phase 3", Rep, 23440-3-9135/01=XSG, 200 pp., Univ. of Alberta, Edmonton, Alberta, Canada (1995).

15) Fetter C.W., Applied Hydrogeology, Prentice Hall, Upper Saddle River, NJ (2001).

16) Freer J., Beven K.J., Ambroise B, "Bayesian estimation of uncertainty in runoff prediction and the value of data: An application of the GLUE approach", Water Resources Research 32(7), 2161-2173 (1996). DOI 10.1029/95WR03723

17) Gupta, H., H. Kling, K. Yilmaz, and G. Martinez, "Decomposition of the mean squared error and NSE performance criteria: Implications for improving hydrological modeling", J. Hydrol. 377(1-2), 8091(2009).

18) Gupta, H. V., H. Kling, "On typical range, sensitivity, and normalization of Mean Squared Error and Nash-Sutcliffe Efficiency type metrics", Water Resour. Res., 47, W10601, (2011). doi:10.1029/2011WR010962.

19) Hamon W.R., "Estimating potential evapotranspiration. Journal of the Hydraulics Division", Proceedings of the American Society of Civil Engineers 87(3), 107-120 (1961).

20) H. Lee et al., "Predictions of rainfall-runoff response and soil moisture dynamics in a microscale catchment using the CREW model", Hydrol. Earth Syst. Sci., 11, 819-849 (2007).

21) Nash, J.E., Sutcliffe, J.V., "River flow forecasting through. Part I. A conceptual models discussion of principles", Journal of Hydrology, 10, 282-290 (1970).

22) Nobert, Joel, Jiben Jeremiah, "Hydrological response of watershed systems to land use/cover change: a case of Wami River Basin", Open Hydrology Journal 6, 78-87 (2012).

23) Nourani V., Roughani A., Gebremichael M., "TOPMODEL capability for rainfall-runoff modeling of the Ammameh watershed at different time scales using different terrain algorithms", Journal of Urban and Environmental Engineering
5(1), 1-15 (2011).

24) Shakoor, A., Ruof, M.A., "Stability of selected coal mine waste embankments in east-central Ohio", Bulletin of the Association of Engineering Geologists, 26, 369-386 (1989).

25) Schaefli, B., H. V. Gupta, "Do Nash values have value?", Hydrol. Processes, 21(15), 2075-2080, (2007). doi:10.1002/hyp.6825

26) Sun, S., H. Deng, "A study of rainfall-runoff response in a catchment using TOPMODEL", $A d v$. Atmos. Sci., 21, 87-95, (2004).

27) Tarboton, D. G., "A new method for the determination of flow directions and upslope areas in grid digital elevation models", Water Resour. Res., 33, 309-319 (1997).

28) White W.W. III, Lapakko K.A., Cox R.L., "Static-Test Methods Most Commonly Used To Predict Acid-Mine Drainage", in Plumlee Gs, Logsdon $\mathrm{Mj}$ (Eds), The Environmental Geochemistry Of Mineral Deposits, Part A: Processes, Techniques, And Health Issues, Rev Econ Geol, 6A, 325-338 (1999).

29) Zanon, Carlo, Watershed Hydrologic Modeling to Assess Interbasin Groundwater Flow in a Tropical Rainforest. Marine, Earth and Atmospheric Sciences, Raleigh, North Carolina (2011). 